\title{
Strategi Menyiapkan Kompetensi SDM Bankir Dalam Disrupsi Era Financial Technology 4.0
}

\author{
Rio Aji Sutrisno ${ }^{1}$, Umanto Eko Prasetyo ${ }^{2}$ \\ Fakultas Ilmu Administrasi Universitas Indonesia \\ rio.aji.sutrisno@gmail.com, umanto.eko@gmail.com
}

\begin{abstract}
Abstrak
Pada era industri 4.0 sistem informasi dan pertukaran data menjadi lebih baik sehingga terjadi beberapa perubahan dalam tren perekonomian salah satunya adalah pembayaran dan penyimpanan uang. Sistem pembayaran dan penyipanan uang saat ini tidak hanya di dominasi oleh perbankan tetapi juga mulai bermunculan perusahaan financial technology (fintech). Dalam perkembangannya fintech telah memasuki era fintech 4.0 dimana fintech telah berkembang dengan memudahkan sistem keuangan dan di khawatirkan dapat menjadi ancaman bagi dunia perbankan konvensional. Oleh karena itu penelitian ini bertujuan untuk menyusun strategi kompetensi yang dibutuhkan oleh perbankan dalam menghadapi distrupsi era fintech 4.0 dengan pendekatan kuantitatif (post positivist).
\end{abstract}

Kata kunci: Fintech, Perbankan, Kompetensi.

\begin{abstract}
In the industrial era 4.0 information systems and data transition for the better occurred in changes in spending trends one of which is payment and money storage. The current system of payment and money deposits is not only dominated by banks but also began to emerge financial technology companies (fintech). In its development fintech has launched the era of fintech 4.0 while fintech has developed by facilitating the financial system and it is feared that it can be a challenge for the conventional banking world. Therefore this study aims to develop competency strategies needed by banks in the era of fintech 4.0 distruction this research using quantitative (post positivist) approach.

Keywords : 3-9 keywords in English
\end{abstract}

\section{PENDAHULUAN}

Revolusi industri 4.0 dipicu oleh teknologi dan sistem informasi yang berkembang dengan pesat hingga mengubah sistem keuangan secara global. Financial technology (fintech) sebagai salah satu dampak dari revolusi industri 4.0, mengubah kebiasaan masyarakat khususnya perilaku dalam melakukan transaksi keuangan. Pada saat ini, digitalisasi sitem keuangan sudah terjadi di berbagai sektor jasa keuangan mulai dari perbankan yang telah sudah mengeluarkan bank digital sehingga memungkinkan nasabah untuk membuat rekening dan melakukan berbagai transaksi keuangan hanya melalui aplikasi smartphone. Selain perbankan, sejak tahun 2007 muncul beberapa perusahaan financial digital seperti Doku sebagai layanan pembayaran elektronik dan manajemen resiko pertama di Indonesia. Selain Doku pada tahun 2014 muncul Tunaiku sebagai Fintech Lending peratama di Indonesia. Setelah itu mulailah muncul banyak industri keuangan baru berbasis teknologi yang disebut Fintech.

Menurut Triyono "finansial teknologi itu adalah suatu kegiatan yang berbasis pada layanan jasa keuangan tapi menggunakan teknologi". Sementara National Digital Research Center (NDRC) mendefinisikan fintech sebagai istilah yang dapat digunakan untuk merujuk pada inovasi di bidang jasa keuangan atau keuangan. Inovasi yang dimaksud adalah inovasi finansial yang diberi sentuhan teknologi modern. 


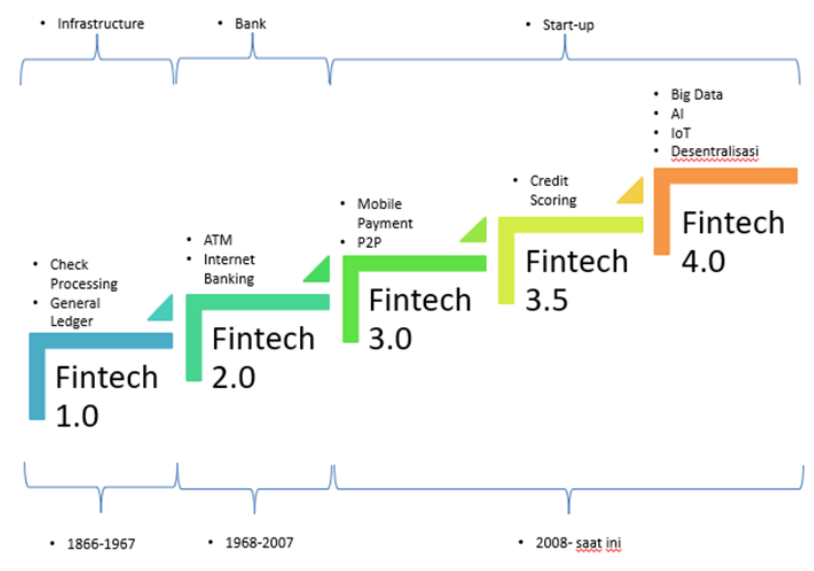

Gambar 1. Perkembangan Fintech

Sumber: Grup Inovasi Keuangan Digital OJK

\section{Fintech 1.0}

Fintech awal mula berkembang sekitar tahun 1866-1967 yang kemudian disebut dengan era fintech 1.0, bertujuan untuk melakukan proses pengecekan sampai dengan pembuatan laporan keuangan.

\section{Fintech $\mathbf{2 . 0}$}

Pada tahun 1968-2007, merupakan era fintech 2.0 yang didukung dengan munculnya komputer dan jaringan internet. Pada 1980-an menjadi banyak bank di dunia mulai memanfaatkan sistem perekaman data yang dapat diakses melalui komputer dan fintech mulai diterapkan pada sistem perbankan yang berbasis elektronik. Tujuannya untuk mendapatkan sistem keuangan yang lebih efisien dan memaksimalkan calon investor potensial. Tahun 1990 muncul beberapa saham online yang memudahkan calon investor untuk menginvestasikan modalnya. Kemudian tahun 1998 perbankan di dunia mulai memperkenalkan perbankan online kepada para pelanggannya. Lembaga jasa keuangan mulai menggunakan teknologi digital untuk memaksimalkan pelayanannya agar semakin praktis dan mudah dengan adanya Automatic Teller Machine (ATM) dan internet banking.

\section{Fintech 3.0}

Era fintech 3.0 dimulai tahun 2008 yang ditandai dengan munculnya start-up dalam bentuk aplikasi yang dapat digunakan pada smartphone. Fintech 3.0 dapat didefinisikan sebagai perusahaan yang tidak memiliki lisensi layanan keuangan yang biasanya merupakan perusahaan teknologi dan komunikasi, tetapi mampu memberikan layanan keuangan untuk konsumen.

Fintech 3.0 menawarkan perubahan baru dimana perusahaan dan layanan yang ditawarkan belum pernah terjadi sebelumnya. Selain itu, model bisnis yang disajikan oleh perusahaan yang dikategorikan sebagai fintech 3.0 juga berbeda. Jenis fintech juga mengalami perkembangan. Tidak hanya sebatas untuk pembayaran tetapi juga merambah pada investasi, pembayaran cicilan kredit hingga pinjam dana. Pada fintech 3.0 tidak ada kantor, bergantung pada platform online, dan layanannya juga disatukan dengan sektor-sektor yang sudah ada sebelumnya.

\section{Fintech 4.0}

Fintech 4.0 ditandai dengan adanya sistem informasi dan pertukaran data yang meliputi, penggunaan Big Data, Artificial Intelegence (AI), Internet of Things (IOT), dan desentralisasi sebagai bagian utama dalam perkembangan fintech. Layanan ini mengkombinasikan layanan pembiayaan atau pinjaman investasi. Dengan pertumbuhan fintech yang cepat, peta persaingan antara fintech dan jasa keuangan konvensional akan semakin ketat, persaingan tidak akan bersifat sektoral dan sebaliknya akan menjadi persaingan bebas. Pada era fintech 4.0 ini banyak hal berubah terutama pemanfaatan teknologi da kecerdasan buatan atau disebut juga Artificial Intelegence hal ini cukup berpengaruh bagi dunia perbankan.

Sejak tahun 2015, jumlah kantor cabang bank umum terus turun hal ini tidak terlepas dari digitalisasi layanan perbankan. Kondisi penurunan jumlah kantor cabang bank dapat dilihat pada Gambar 2. Digitalisasi layanan perbankan menggantikan banyak peran karyawan dan kantor cabang mulai dari mesin pencetak kartu atm, pembuatan rekening dari smartphone hinga layanan perbankan lainnya yang dapat dilakukan dari mobile banking. 


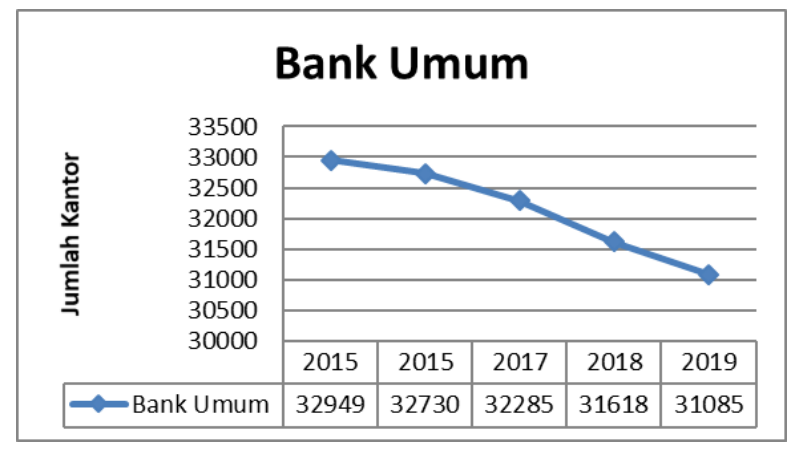

Gambar 2. Statistik Jumlah Kantor Bank Umum Sumber: Departemen Informasi Perbankan OJK

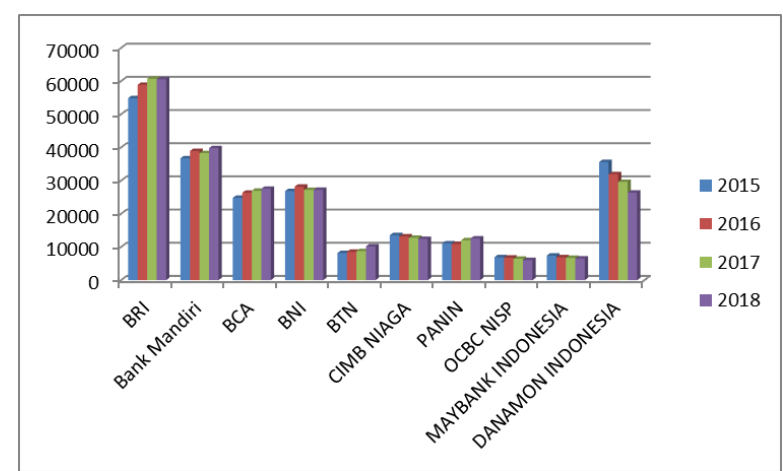

Gambar 3. Statistik Jumlah Pegawai Bank

Sumber: Laporan Keuangan Masing-Masing Bank

Selain berdampak pada berkurangnya kantor cabang bank umum transformasi fintech 4.0 juga berdampak pada berkurangnya pegawai perbankan. Gambar 3 menunjukkan gambaran jumlah pegawai bank yang semakin menurun pada beberapa bank di Indonesia. Jumlah pegawai perbankan berdasarkan data laporan keuangan masing-masing Bank memiliki jumlah penambahan yang melambat bahkan beberapa Bank seperti Bank Danamon melakukan pengurangan pegawai, Bank CIMB Niaga yang memberikan program pensiun dini bagi pegawai dan beberapa bank lain yang memilih tidak merekrut pegawai baru terutama untuk bagian front liner.

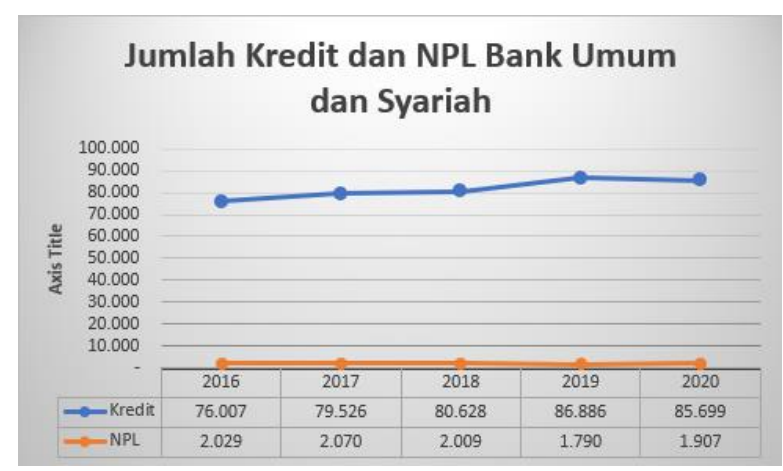

Gambar 4. Jumlah Kredit dan NPL Bank Umum dan Syariah

Sumber: Departemen Informasi Perbankan OJK

Jumlah kredit dari Bank Umum dan Syariah dari tahun 2016 relatif stagnan. Hal ini tidak mencerminkan penghasilan bersih dari perbankan seperti contohnya berdasarkan data laporan keuangan pada Bank Danamon. Pada 2015, biaya operasional Danamon adalah Rp14,43 triliun. Setelah tiga tahun, biaya operasional turun 12 persen menjadi Rp12,77 triliun.

Pendapatan selama 2018 turun 10 persen menjadi Rp20,17 triliun dari 2015 sebesar Rp22,42 triliun, laba bersih 2018 Danamon naik 66 persen menjadi Rp4,1 triliun dari 2015 sebesar Rp2,46 triliun. Ini menandakan bank lebih

efisien.

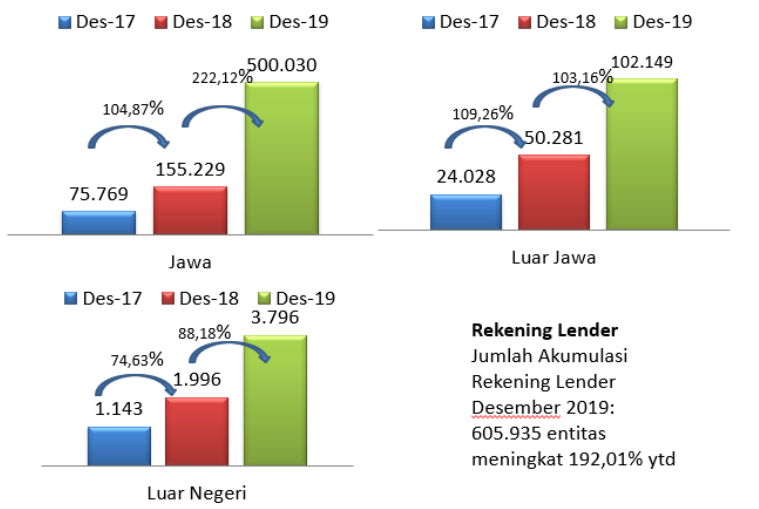

Gambar 5. Perkembangan Rekening Lender di Indonesia

Sumber : Data Direktorat Pengaturan, Perizinan dan Pengawasan Fintech

Berbeda dengan perbankan yang relatif stagnan salah satu industri baru dari fintech 4.0 mengalami perkembangan yang sangat pesat. Berdasarkan data pada Desember 2017-2019 menunjukkan bahwa jumlah fintech khusunya untuk fintech P2P atau fintech Lending terus bertambah. Hal ini dapat dilihat pada peningkatan jumlah pemberi pinjaman (lender) dan peminjam (borrower) dari tahun ke tahun. Lender dalam fintech Lending di indonesia masih di dominasi oleh Lender dari pulau jawa sejumlah 500.030 Lender atau $82,52 \%$ dari jumlah seluruh rekening lender. Selain itu peningkatan tiap tahun pada jumlah lender cukup signifikan yaitu sebesar 192,01\% pada bulan Desember 2019. 


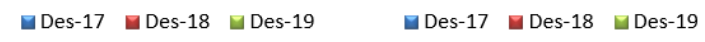

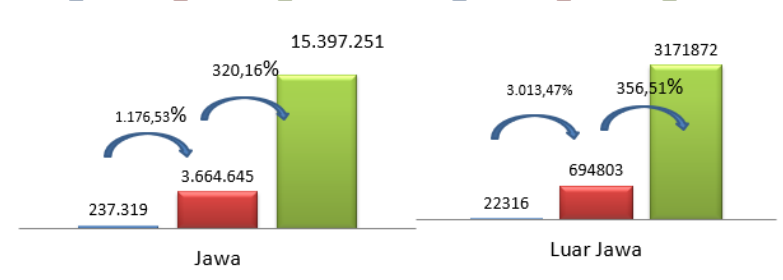

Gambar 5. Perkembangan Rekening Borrower di Indonesia

Sumber : Data Direktorat Pengaturan, Perizinan dan Pengawasan Fintech

Sementara untuk jumlah rekening borrower (peminjam) juga masih di dominasi oleh peminjam dari pulau jawa yaitu sebanyak 15.397.251 akun atau 82,92\% dengan peningkatan sebesar $325,95 \%$ akun dari bulan Desember tahun 2018.

Jumlah akumulasi rekening borrower Bulan Desember 2019 sejumlah 18.568.123 entitas meningkat $325,95 \%$ dalam satu tahun. Perkembangan Fintech Peer to Peer Lending juga bukan hanya dari jumlah akun Lender dan Borrower tetapi juga terlihat dari peningkatan jumlah penyaluran pinjaman dimana terjadi peningkatan sebesar $259,56 \%$ atau senilai 81,5 triliun rupiah pada bulan Desember tahun 2019 dibandingkan bulan Desember tahun 2018.

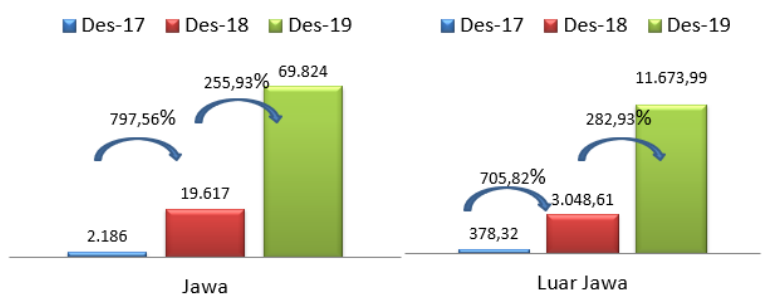

Gambar 6. Akumulasi jumlah pinjaman fintech lending di Indonesia 2019

Sumber : Data Direktorat Pengaturan, Perizinan dan Pengawasan Fintech

Sementara untuk Akumulasi jumlah pinjaman Desember 2019: Rp81,5 Triliun meningkat 259,56\% dari bulan Desember 2018. Peningkatan ini cukup tinggi apabila dibandingkan dengan jumlah kakumulasi pemberian kredit perbankan.

Dengan dimulainya era fintech 4.0 memberikan beberapa perubahan pada industri jasa keuangan baik dengan banyaknya pengurangan jumlah kantor cabang maupun karyawan pada Bank Umum. Pada lain sisi industri fintech terus berkembang dengan pesat. Hal inilah yang membuat penulis tertarik untuk meneliti tentang kompetensi apa yangdibutuhkan oleh perbankan dalam era fintech 4.0.

Penelitian ini bertujuan untuk menyusun strategi kompetensi yang dibutuhkan oleh perbankan dalam menghadapi distrupsi era fintech 4.0 dengan pendekatan kuantitatif (post positivist) dimana 3 kompetensi utama yang dibutuhkan oleh perbankan untuk bisa melalui distrupsi era fintech 4.0 adalah desingner, programer dan creative thinker.Oleh karena itu, perbankan harus mampu bersaing dan menyusun startegi yang tepat dalam menanggapi perubahan yang cepat pada industri keuangan.

\section{Rumusan Masalah}

Berdasarkan pemikiran di atas adapun rumusan masalah yang akan dibahas dalam penelitian ini:

1. Bagaimana pengaruh Fintech terhadap pasar (market bussiness) perbankan?

2. Bagaimana kondisi kompetensi SDM Bankir di Indonesia saat ini?

3. Kompetensi SDM apa yang diperlukan Bankir dalam menghadapi Fintech 4.0 ?

\section{Tujuan Penelitian}

Berdasarkan permasalahan di atas tujuan dari penelitian ini adalah:

1. Menganalisis pengaruh Fintech Peer to Peer Lending bagi perbankan.

2. Menganalisis kondisi kompetensi SDM Bankir di Indonesia.

3. Menganalisis kompetensi SDM apa yang diperlukan Bankir dalam menghadapi Fintech 4.0

\section{Manfaat Penelitian}

\section{Signifikansi Akademis}

Secara akademis penelitian ini memiliki tujuan untuk menambah wawasan dan sebagai pengembangan ilmu pengetahunan mengenai mengenai kompetensi SDM Bankir di Indonesia era fintech 4.0 Selain itu penelitian ini bisa menjadi referensi atau sumber informasi bagi penelitian selanjutnya.

\section{Signifikansi Praktis}

Secara praktis diharapkan penelitian ini dapat menjadi salah satu bahan bagi Perbankan dalam menyiapkan strategi kompetensi apa yang dibutuhkan oleh Bankir dalam menghadapi Era 
Financial Technology 4.0 khususnya bagi lembaga asal Penulis itu Otoritas Jasa Keuangan dalam mempersiapkan kebijakan.

Berisi desain penelitian, deskripsi cara melakukan penelitian termasuk populasi dan sampel, instrumen dan metode pengumpulan data, teknik analisis data. Hasilnya menyajikan karakteristik data dan temuan penelitian.

Tabel 3. Operasionalisasi Konsep

\begin{tabular}{|c|c|c|c|c|}
\hline $\begin{array}{l}\text { वे } \\
\bar{u}\end{array}$ & $\overline{\underline{0}}$ & \multicolumn{2}{|c|}{ Dimensi } & Indikator \\
\hline \multirow{8}{*}{ 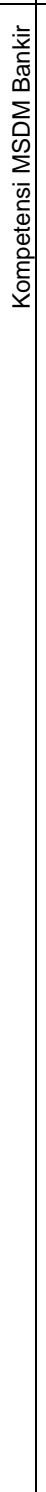 } & \multirow{8}{*}{ 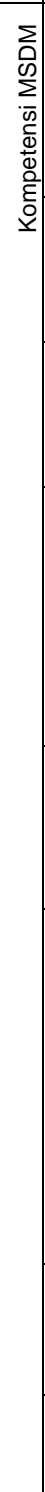 } & \multirow[t]{3}{*}{$\begin{array}{l}\text { Strategic } \\
\text { (Organization) } \\
\text { Enablers }\end{array}$} & $\begin{array}{l}\text { Human } \\
\text { Capital } \\
\text { Curator }\end{array}$ & $\begin{array}{l}\text { Pengembangan Bakat } \\
\text { Mengembangkan } \\
\text { Pimpinan } \\
\text { Mendorong Performa } \\
\text { Mengembangkan } \\
\text { Teknis Bakat }\end{array}$ \\
\hline & & & $\begin{array}{l}\text { Culture and } \\
\text { Change } \\
\text { Champion }\end{array}$ & $\begin{array}{l}\text { Desain Budaya } \\
\text { Mengelola Perubahan }\end{array}$ \\
\hline & & & $\begin{array}{l}\text { Total Rewards } \\
\text { Steward }\end{array}$ & $\begin{array}{l}\text { Desain Kerja Berarti } \\
\text { Mengembangkan } \\
\text { Pimpinan }\end{array}$ \\
\hline & & \multirow[t]{2}{*}{$\begin{array}{l}\text { Core } \\
\text { Competencies }\end{array}$} & $\begin{array}{l}\text { Strategic } \\
\text { Positioner }\end{array}$ & $\begin{array}{l}\text { Penafsiran Konteks } \\
\text { Bisnis } \\
\text { Menerjemahkan } \\
\text { Harapan Pemangku } \\
\text { Kepentingan } \\
\text { Memahami } \\
\text { Operasional Bisnis } \\
\text { Internal }\end{array}$ \\
\hline & & & $\begin{array}{l}\text { Credible } \\
\text { Activist }\end{array}$ & $\begin{array}{l}\text { Mempengaruhi dan } \\
\text { Berkaitan dengan } \\
\text { Orang Lain } \\
\text { Dapatkan Kepercayaan } \\
\text { Melalui Hasil }\end{array}$ \\
\hline & & \multirow[t]{3}{*}{$\begin{array}{l}\text { Delivery } \\
\text { Enablers }\end{array}$} & $\begin{array}{l}\text { Compliance } \\
\text { Manager }\end{array}$ & $\begin{array}{l}\text { Memastikan bahwa } \\
\text { praktik SDM mematuhi } \\
\text { hukum pemerintah } \\
\text { Berdiri untuk hak-hak } \\
\text { karyawan } \\
\text { Mendidik karyawan dan } \\
\text { manajer secara aktif } \\
\text { tentang cara mematuhi } \\
\text { pedoman hokum } \\
\text { tentang perilaku di } \\
\text { tempat kerja }\end{array}$ \\
\hline & & & $\begin{array}{l}\text { Analytics } \\
\text { Designer and } \\
\text { Implementer }\end{array}$ & $\begin{array}{l}\text { Mendapatkan Data } \\
\text { yang Tepat } \\
\text { Menafsirkan Data } \\
\text { Bisnis }\end{array}$ \\
\hline & & & $\begin{array}{l}\text { Technology } \\
\text { and Media } \\
\text { Integrator }\end{array}$ & $\begin{array}{l}\text { Memanfaatkan Media } \\
\text { Sosial } \\
\text { Teknologi terintegrasi }\end{array}$ \\
\hline
\end{tabular}

Inovasi menurut Nick Skillicorn (2019) adalah "An innovation is turning an idea into a solution that adds value from a customer's perspective" dimana sebuah inovasi adalah merubah ide menjadi solusi yang menambah nilai dari perspektif pelanggan sehingga dapat dikatakan inovasi merupakan solusi yang dilakukan dengan mempertimbangkan pandangan pelanggan sebagai dasar. Dari definisi ini kita dapat melihat bahwa inovasi adalah sesuatu yang baru dan berguna yang membedakan Anda.

Sementara Paul Sloane (2013) mengatakan "An innovation is creativity is thinking of something new. Innovation is the implementation of something new."

Kompetensi menurut Dubois dan Rothwell (2004) adalah karakteristik yang dimiliki dan digunakan individu dengan cara yang konsisten dan tepat untuk mencapai suatu kinerja yang diinginkan. Karakteristik ini termasuk keterampilan, pengetahuan, motif sosial, aspek citra diri, ciri-ciri, pola pikir, cara berpikir, perasaan, dan akting. Kompetensi membentuk dasar manajemen SDM berbasis kompetensi praktik. Interpretasi makna kompetensi adalah cukup bervariasi. Sekilas tentang sejarah pergerakan kompetensi mungkin akan memberi pemahaman yang lebih baik tentang istilah itu telah didefinisikan dan digunakan dalam manajemen SDM.

Kompetensi perbankan menurut Lembaga Sertifikasi Profesi Perbankan (LSPP) secara umum terbagi menjadi : Manajemen Risiko, Treasury, Audit, Wealth Management, Compliance, Credit, Operation dan Funding \& Services. Sedangkan potensi kebutuhan sertifikasi perbankan terus meningkat dengan perkiran kebutuhan sertifikasi pada tahun 2019 sebanyak 1.064 .540 orang.

Menurut Hasibuan (2009) Bank adalah badan usaha yang mengumpulkan dana dari masyarakat dalam bentuk simpanan dan mendistribusikannya kepada masyarakat dalam bentuk pinjaman dan / atau bentuk lain untuk meningkatkan taraf hidup masyarakat.

Sementara menurut Pierson dalam Hasibuan (2011) "Bank is a company which accept credit, but didn't give credit." Bank adalah entitas bisnis yang menerima kredit tetapi tidak memberikan kredit). Teori ini menyatakan bahwa bank hanya pasif dalam operasinya, yang hanya menerima uang yang disetorkan.

Menurut Stuart dalam Hasibuan (2011) "Bank is a company who satisfied other people by giving a credit with the money they accept as a gamble to the other, eventhough they should supply the new money." (Bank adalah entitas bisnis yang 
bentuknya memenuhi kebutuhan orang lain, dengan memberikan kredit dalam bentuk uang yang diterima dari orang lain, bahkan jika mereka mengeluarkan uang kertas atau koin baru). Jadi bank dalam hal ini telah melakukan operasi pasif dan aktif, yaitu mengumpulkan dana dari orang-orang yang kelebihan dana dan memberikan kredit kepada orang-orang yang membutuhkan dana.

Bank umum adalah bank yang melakukan kegiatan bisnis konvensional dan atau berdasarkan prinsip syariah, yang dalam kegiatannya menyediakan layanan dalam lalu lintas pembayaran.

\section{Fintech}

Menurut Triyono (dalam wawancara mendalam 25 November 2019), fintech adalah sebuah inovasi pada industri jasa keuangan yang memanfaatkan penggunaan teknologi. Produk fintech biasanya berupa suatu sistem yang dibangun guna menjalankan mekanisme transaksi keuangan yang spesifik.

Pada prinsipnya fintech adalah "a fusion between technology and financial services". Penggunaan handphone sebagai layanan mobile banking dan investasi bisa dijadikan sebagai contoh perpaduan teknologi dengan sistem keuangan guna memberikan layanan keuangan yang lebih mudah diakses oleh masyarakat luas (Lenny Sanicola: 2017). Dengan kata lain, fintech bertujuan memberikan kemudahan kepada masyarakat dalam mengakses produk-produk keuangan, mempermudah transaksi dan juga meningkatkan literasi keuangan (Finansialku.com).

Bila dilihat dari jenisnya fintech terbagi menjadi 5 jenis yaitu Fintech Lending, Inovasi Keuangan Digital, Digital Payment, Equity Crowfunding dan Payment Gateway.
TABEL 4: Tabel Perbedaan Jenis Fintech

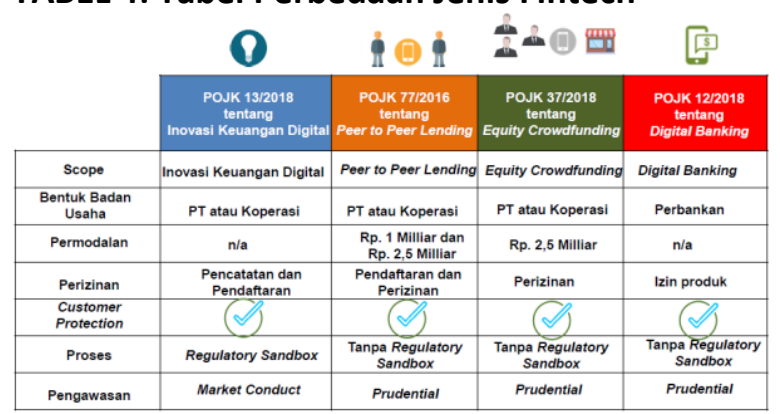

Sumber: Grup Inovasi Keuangan Digital Otoritas Jasa Keuangan

Sementara untuk Payment Gateway diregulasi oleh Bank Indonesia sebagai lembaga yang berwenang terkait pembayaran di Indonesia yang diatur dalam Peraturan Bank Indonesia Nomor PBI 18/40/PBI/2016. Sementara beberapa perbedaan antara Bank dan Fintech Lending dijelaskan dalam tabel 5 .

Tabel 5: Perbedaan Bank dan Fintech Lending

\begin{tabular}{|c|c|c|}
\hline \multicolumn{3}{|c|}{ Perbedaan Bank dan Fintech Lending } \\
\hline Jenis Perbedaan & Bank & Fintech Lending \\
\hline Kegiatan usaha & $\begin{array}{l}\text { Menghimpun dana } \\
\text { simpanan dari masyarakat } \\
\text { umum, menyalurkan } \\
\text { kredit dan pinjaman untuk } \\
\text { korporasi, UMKM, } \\
\text { konsumen, ritel, dan } \\
\text { menjalankan berbagai } \\
\text { transaksi pembayaran, } \\
\text { serta penjualan produk } \\
\text { investasi. }\end{array}$ & $\begin{array}{l}\text { Penyedia platfrom (website atau } \\
\text { aplikasi) perantara antara pemberi } \\
\text { pinjaman dan penerima pinjaman } \\
\text { untuk melakukan transaksi pinjam } \\
\text { meminjam berdasarkan perjanjian } \\
\text { melalui sistem elektronik. }\end{array}$ \\
\hline $\begin{array}{l}\text { Sumber dana } \\
\text { pinjaman }\end{array}$ & $\begin{array}{l}\text { Tabungan, deposito, giro, } \\
\text { modal pemilik, dan } \\
\text { penerbitan surat utang. }\end{array}$ & $\begin{array}{l}\text { Orang atau badan hukum yang } \\
\text { memiliki dana dan ingin } \\
\text { meminjamkannya kepada pihak lain. }\end{array}$ \\
\hline $\begin{array}{l}\text { Pemberi } \\
\text { pinjaman }\end{array}$ & Bank. & $\begin{array}{l}\text { Orang atau badan hukum sebagai } \\
\text { pemilik dana (bukan perusahaan } \\
\text { fintech lending) }\end{array}$ \\
\hline $\begin{array}{l}\text { Risiko } \\
\text { penyaluran } \\
\text { pinjaman }\end{array}$ & Ditanggung bank. & Ditanggung pemberi pinjaman. \\
\hline $\begin{array}{l}\text { Kewenangan } \\
\text { pemberian } \\
\text { restrukturisasi }\end{array}$ & Bank. & $\begin{array}{l}\text { Pemberi pinjaman (sebagai pemilik } \\
\text { dana). Perusahaan fintech lending } \\
\text { hanya dapat memberikan } \\
\text { restrukturisasi pinjaman setelah } \\
\text { mendapatkan persetujuan dari } \\
\text { pemberi pinjaman. }\end{array}$ \\
\hline Pengawasan & $\begin{array}{l}\text { Pengawasan atas bank } \\
\text { sebagai lembaga } \\
\text { kepercayaan yang } \\
\text { menghimpun dana } \\
\text { masyarakat }\end{array}$ & $\begin{array}{l}\text { Pengawasan terhadap } \\
\text { penyelenggara fintech sebagai } \\
\text { perantara (platform) dalam } \\
\text { melaksanakan market conduct } \\
\text { antara pemberi pinjaman dan } \\
\text { penerima pinjaman. }\end{array}$ \\
\hline
\end{tabular}

Sumber: Grup Inovasi Keuangan Digital OJK 


\section{Manajemen Sumber Daya Manusia}

Dalam banyak teori, Manajemen Sumber Daya Manusia sudah didefinisikan dalam bermacammacam cara. Tapi yang penting untuk definisi apapun adalah pemahaman bahwa organisasi yang efektif harus mampu untuk menemukan, penggunaan, menjaga, dan mengembangkan manusia untuk mencapai suatu hasil. Manajemen SDM adalah suatu proses untuk membantu organisasi melakukan hal itu. Cara di mana organisasi mengelola orang-orang mereka adalah sumber potensial dari keunggulan kompetitif berkelanjutan. Sherman, Bohlander, dan Snell (1998) mencatat, "istilah 'sumber daya manusia' menyiratkan bahwa orang memiliki kemampuan yang mendorong kinerja organisasi (bersama dengan sumber lain seperti uang, bahan, informasi, dan sejenisnya). istilah lain seperti 'modal manusia' dan 'aset intelektual' semua memiliki kesamaan gagasan bahwa orang membuat perbedaan dalam bagaimana organisasi melakukan".

Ekonom pemenang Hadiah Nobel Theodore W. Schultz adalah orang pertama yang menggunakan istilah modal manusia dalam artikel "Investasi di Human Capital," yang muncul dalam American Economic Review pada tahun 1961 (Davenport, 1999).

Jac Fitz-enz, pemimpin dalam benchmarking kinerja sumber daya manusia, menunjukkan bahwa Pengetahuan, keterampilan, dan sikap tenaga kerja memisahkan perusahaan pemenang dari juga-rans. Ini adalah kombinasi kompleks faktor. Namun, orang per se bukan satu-satunya kekuatan di balik kekuatan inheren dari modal manusia. Jika kunci untuk penciptaan kekayaan hanya hitungan kepala, maka membosankan, tingkat terendah orang akan sama berharganya dengan terang, tingkat tertinggi orang. Pada kenyataannya, itu adalah informasi bahwa orang yang memiliki dan nya kemampuan dan kemauan untuk berbagi yang menetapkan nilai potensial. Data dan orangorang tak terelakkan terkait yang belum pernah sebelumnya. Salah satu tanpa yang lain suboptimized. (Fitz-enz, 2000)

Fitz-enz (2000) juga menyarankan bahwa "kunci untuk mempertahankan perusahaan yang menguntungkanatau ekonomi yang sehat adalah produktivitas tenaga kerja, modal manusia kita". modal manusia adalah topik dari banyak diskusi dalam organisasi hari ini. Hal ini juga menjadi subyek dari sejumlah studi penelitian. Syarat modal manusia ditafsirkan secara berbeda, bagaimanapun, tergantung pada Sebuah sudut pandang. Misalnya, Ulrich, Zenger, dan Smallwood (1999) yang tergabung perbedaan yang mereka lihat antara apa yang karyawan dapat melakukan dan akan melakukan ke dalam definisi terukur berikut modal manusia: kemampuan karyawan dikalikan dengan komitmen karyawan.

\section{Model Kompetensi MSDM 2017 Ulrich}

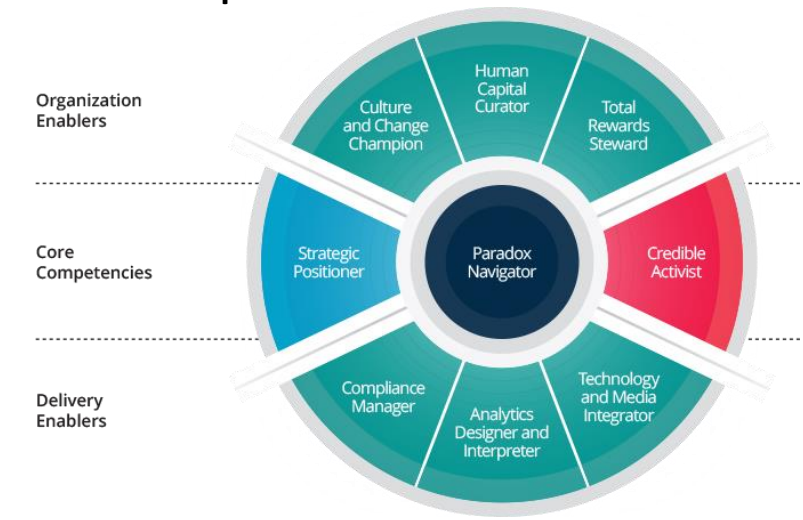

Gambar 7. 2016 HR Competency Model

Sumber: Human Resource Competency Conference 2016 (diolah kembali)

\section{Perincian Penentu Positioner Strategis}

Domain positioner strategis menangkap sejauh mana profesional HR dapat mengevaluasi konteks bisnis eksternal dan internal dan menerjemahkan evaluasi tersebut menjadi praktis wawasan yang membantu memposisikan organisasi untuk menjadi sukses.

\section{Rincian Aktivis Kredibel}

Domain aktivis yang kredibel melanjutkan dari studi sebelumnya dan menangkap sejauh di mana para profesional SDM mencapai kepercayaan dan rasa hormat yang mereka butuhkan dalam organisasi dipandang sebagai mitra yang berharga dan berharga.

\section{Paradox Navigator Breakdown}

Profesional SDM semakin diminta untuk memaksimalkan gagasan dan hasil yang mungkin dicapai secara inheren bertentangan satu sama lain. Para profesional ini harus terus mengelola paradoks atau ketegangan yang ada di lingkungan kerja

\section{Rincian Budaya dan Juara Perubahan}

Profesional SDM perlu mengelola perubahan dan budaya. Dengan memperjuangkan perubahan dan budaya, profesional SDM 
membantu mewujudkan berbagai hal secara konsisten.

\section{Human Capital Curator Breakdown (Rincian Kurator Sumber Daya Manusia)}

Profesional SDM menawarkan solusi SDM yang terintegrasi dan inovatif untuk mengelola orang dalam organisasi mereka. Area praktik SDM ini memastikan sumber daya manusia.

Total Reward Steward (Total Hadiah Steward) Profesional SDM harus mampu menciptakan sistem hadiah total yang mencakup kompensasi dan manfaat (imbalan finansial) serta makna dari pekerjaan (imbalan non finansial).

\section{Teknologi dan Penyesuaian Media}

Profesional SDM harus mampu memanfaatkan teknologi dan alat teknologi untuk mendukung upaya mereka untuk menciptakan organisasi berkinerja tinggi. Mereka juga mengandalkan media sosial untuk merekrut, mempertahankan, mengembangkan, dan melibatkan sumber daya manusia.

\section{Desainer analisis dan penafsiran}

Profesional SDM harus dapat menggunakan analitik untuk mempengaruhi pengambilan keputusan. Analytics melampaui pengumpulan data dan memiliki kartu skor untuk menggunakan data untuk meningkatkan keputusan bisnis.

\section{Manajemen SDM Berbasis Kompetensi}

Kita melihat bahwa manajemen sdm berbasis kompetensi tidak lagi cukup untuk fokus pada aktivitas kerja dan pekerjaan. Manajemen SDM berbasis kerja tidak dapat bersaing dengan laju perubahan. Selain itu, fokus pada aktivitas kerja tidak mengarahkan perhatian manajemen kinerja yang diinginkan atau hasil, juga tidak memungkinkan organisasi untuk memanfaatkan produktivitas yang tinggi pemain teladan.

Sebaliknya, manajemen SDM berbasis kompetensi berkonsentrasi pertama pada orang tersebut dan kemudian pada output atau hasil. Kompetensi yang abadi, sementara aktivitas kerja dan tugas-tugas pekerjaan tertentu bersifat sementara. Model kompetensi dapat melengkapi deskripsi pekerjaan tradisional dan menjadi dasar untuk seluruh sistem. Kapan SDM yang terjadi, sebuah organisasi menggunakan manajemen SDM berbasis kompetensi. Dalam penerapan manajemen SDM berbasis kompetensi memandang output diperlukan dan peran pekerjaan organisasi atau persyaratan dari orang-berorientasi daripada perspektif berorientasi pekerjaan. Pendekatan ini membuat kompetensi dasar bagi seluruh fungsi manajemen SDM.

Kompetensi mendorong rekrutmen, seleksi, penempatan, orientasi, pelatihan, manajemen kinerja, dan manfaat pekerja. Dengan semua aspek manajemen SDM yang terintegrasi melalui kompetensi, bukan melalui pemikiran tradisional tentang pekerjaan atau aktivitas kerja, organisasi memiliki sistem HR berbasis kompetensi. Teladan, tidak sepenuhnya berhasil, kinerja adalah tujuan dari kebanyakan organisasi dengan sistem berbasis kompetensi. Kompetensi karena itu harus valid dan dapat diandalkan dalam membedakan pemain teladan dan sepenuhnya berhasil.

Jika digunakan dengan benar, manajemen SDM berbasis kompetensi memiliki potensi untuk memenuhi berbagai kebutuhan bisnis. Hal ini dapat, misalnya, menjadi nilai bagi organisasi yang berusaha untuk mencapai tujuan sebagai berikut:

- Meningkatkan keunggulan kompetitif

- Mengembangkan kualitas yang lebih baik dalam produk dan layanan

- Meningkatkan produktivitas

- Posisi organisasi untuk pertumbuhan di masa depan

- Memfasilitasi perubahan budaya dan transformasi

- Membantu dengan perubahan organisasi skala besar

- Hasil asuh positif dengan pelanggan atau pemasok

- Meningkatkan kinerja keuangan

- Membangun hubungan sistematis dan integrasi antara praktek manajemen SDM

- Menyelaraskan praktik manajemen SDM dengan misi, visi, nilai-nilai, atau strategi bisnis atau tujuan dari organisasi Selain mengejar tindakan yang tercantum di atas, organisasi mengadopsi praktik manajemen SDM berbasis kompetensi karena beberapa alasan utama.

\section{Kompetensi dan Daya Saing}

Peneliti melaporkan hasil sebuah studi 1997 dimana mereka meneliti trend dan dieksplorasi orang strategi. Penelitian ini didasarkan pada tanggapan survei dari 1.020 organisasi Amerika Utara, penelitian mendalam kasus yang dilakukan dengan tujuh belas perusahaan, dan evaluasi di lokasi dan wawancara. 
Peran kompetensi adalah salah satu daerah yang ditinjau. Mencatat bahwa kompetensi dapat menentukan dan menyampaikan strategi organisasi dan maknanya dan membantu karyawan dalam memahami strategi dan mencapai tujuan, laporan menunjukkan peran kompetensi dalam organisasi, termasuk mengartikulasikan nilai-nilai organisasi; menyediakan bahasa umum yang menggambarkan penciptaan nilai; menciptakan paradigma baru untuk program di HR (tugas organisasi); menekankan pengembangan individu bukan struktur organisasi; menghubungkan gaji, promosi, dan pertumbuhan apa organisasi dianggap menjadi nilai; dan membimbing karyawan dan manajer mengenai harapan serta bagaimana nilai didefinisikan selama perubahan dan restrukturisasi. Hasil penelitian menunjukkan bahwa praktek berbasis kompetensi kontribusi positif ke baris bawah, dan bahwa kontribusi kepada organisasi terkait dengan peran individu bukan untuk pekerjaan mereka.

Selain itu, hasil menunjukkan bahwa upaya yang dirancang untuk komitmen karyawan lebih memiliki potensi untuk menghasilkan keuntungan yang positif, dan bahwa pelatihan dan pengembangan dipandang sebagai driver dari kesuksesan masa depan.

Dalam sebuah wawancara dengan beberapa praktisi di lapangan, subjek model kompetensi dibahas Brackey (1998). Setelah keterampilan pemain terbaik dikenal, model kompetensi memberikan nilai dan kegunaan baik untuk pelatihan dan motivasi dan sebagai dasar untuk memperoleh kompetensi organisasi diperlukan untuk mengubah. Termasuk dalam wawancara itu komentar berikut tentang model-model kompetensi.

Ada minat yang tumbuh dalam model kompetensi karena meningkatkan fokus pada individu karena tenaga kerja menjadi lebih berbasis pengetahuan dan bisnis yang lebih berbasis teknologi, menurut Sandra O'Neil Gaffin. Juga, proses yang terlibat dengan menciptakan model sering menempatkan fokus yang kuat pada sumber daya perusahaan dan tujuan, menurut Edward J. Cripe. Salah, mencatat Maxine Dalton, Manajemen Sumber Daya Manusia Berbasis Kompetensi praktek manajemen SDM berbasis kompetensi menghasilkan manfaat yang signifikan bagi organisasi dan karyawan mereka. Nilai menggunakan kompetensi untuk membantu memenuhi kebutuhan bisnis tidak bisa terlalu ditekankan.

\section{Metode}

Dalam studi ini pendekatan penelitian yang digunakan adalah pendekatan kuantitatif (post positivist). Penelitian kuantitatif dinamakan metode tradisional, karena metode ini sudah mentradisi sebagai metode penelitian. Metode penelitian kuantitatif dapat juga diartikan sebagai sebuah metode penelitian berdasarkan filosofi positivisme, yang digunakan untuk memeriksa sampel atau populasi tertentu, pengumpulan data dilakukan dengan menggunakan instrumen penelitian, analisis statistik atau kuantitatif, dengan tujuan menguji hipotesis yang telah ditentukan.

Post-positivisme juga disebut sebagai paradigma interpretif dan konstruktif, yang memandang realitas sosial sebagai sesuatu yang holistik / utuh, dinamis dan kompleks penuh makna dan hubungan simtomatik yang bersifat interaktif (timbal balik).

Penelitian ini mencoba untuk menggambarkan suatu fenomena yaitu Strategi Menyiapkan Kompetensi SDM Bankir Dalam Disrupsi Era Financial Technology 4.0 melalui lalui proses pengumpulan data dan intepretasi data. Sebagai penelitian kualitatif, penelitian ini lebih menekankan pada pemahaman.

\section{Hasil}

Saat ini kondisi fintech di Indonesia sudah sangat berkembang dengan penggunaan teknologi informasi yang di dukung oleh E-KYC, Payment Gateway, Big Data, Cloud Infrastucture, Artificial Intelegence dan tandatangan digital berdasarkan data dari Asosiasi Fintech Indonesia (AFTECH). Peningkatan ini salah satunya dapat dilihat dari jumlah pinjaman di fintech lending dari tahun 2018 ke 2019 yang mengalami peningkatan sebesar $259,56 \%$ berbeda dengan peningkatan kredit perbankan yang hanya meningkat $7 \%$ pada periode yang sama mencatat fungsi intermediasi tumbuh 6,08 persen secara tahunan (year-on-year / yoy). Padahal pada tahun sebelumnya distribusi dana bank ke pihak ketiga tumbuh dua digit atau 11,82 persen yoy. Selain dari jumlah pinjaman menurut data LPS 
jumlah simpanan nasabah bank turun senilai $0,7 \%$ walaupun jumlah rekeningnya bertambah $0,48 \%$.

Survei Perbankan Bank Indonesia menunjukkan bahwa pertumbuhan kredit triwulanan baru melambat pada kuartal 1 - 2020. Ini tercermin dalam saldo bersih tertimbang (SBD) permintaan kredit baru pada kuartal H2020 sebesar 23,7\%, lebih rendah dari $70,6 \%$ pada kuartal sebelumnya dan 57,8\% pada kuartal 1 - 2019. Berdasarkan jenis penggunaan, perlambatan pertumbuhan permintaan untuk pinjaman baru berasal dari semua jenis pinjaman, dengan penurunan terbesar dalam jenis kredit konsumsi. Selain itu dari jumlah kantor dan jumlah pegawai bank mengalami penurunan terkait dengan berkurangnya nasabah yang datang ke bank. Menurut Triyono Kepala Grup Inovasi Keuangan Digital (dalam wawancara mendalam 25 November 2019) "Bank dan fintech itu sesuatu yang berbeda. bank itu bergerak dalam ranah kehati-hatian. Sementara fintech itu ranahnya adalah ranah inovasi. Inovasi itu ya bukan kehatihatian karena dia itu bukan lembaga intermediasi. Itu yang harus kita garis bawahi bahwa bank adalah intermediasi sedangkan fintech adalah non-intermediasi. Oleh karena itu prinsipnya pun beda. Jadi masing-masing punya pangsanya sendiri, itu yang pertama. Tapi faktanya adalah memang betul ada beberapa bisnis bank yang mulai diancam oleh fintech. Salah satunya yang paling dijelas adalah transfer dana ini tadi ya". Senada dengan tanggapan Triyono, Tasa N. Barley dari Asosiasi Fintech Indonesia (AFTECH) (dalam wawancara mendalam tanggal 5 Desember 2019) dan Hugo Massie dari Asosiasi Fintech Pendanaan Bersama Indonesia (AFPI) (dalam wawancara mendalam 17 Desember 2019) juga membenarkan bahwa Fintech dan Perbankan memiliki karateristik dan target yang agak berbeda terutama di Fintech Lending tetapi beberapa perbankan juga mulai masuk sebagai Lender bagi fintech lending.

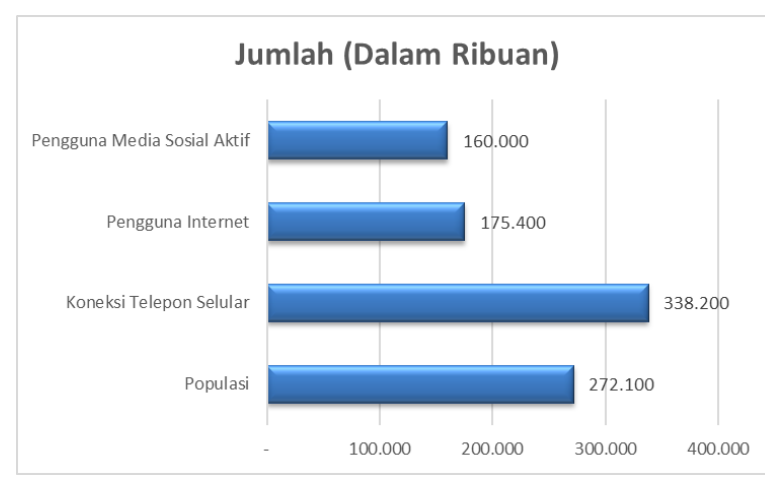

Gambar 8. Jumlah Pengguna Internet di Indonesia Tahun 2019

Sumber: Riset We Are Social dan Hootsuite Soal Internet Indonesia.

Pengguna internet dan telepon selular di indonesia memiliki jumlah yang besar ditambah dengan adanya pandemi covid-19 sehingga penggunaan teknologi financial dan pengurangan tatap muka langsung sangat diperlukan pada saat ini. Bank perlu melakukan inovasi dan peningkatan teknologi agar siap terhadap kondisi pasar saat ini.

Berdasarkan hal tersebut fintech cukup mempengaruhi perbankan terutama pada fintech pembayaran atau payment gateway. Selain hal tersebut era fintech 4.0 juga mengharuskan perbankan untuk berubah karena pasar juga berubah selain meningkatnya penggunaan smartphone untuk jasa keuangan dengan adanya pandemi ini maka perbankan harus brkaca pada fintech meningkatkan kembali penggunaan teknologi E-KYC, Payment Gateway, Big Data, Cloud Infrastucture, Artificial Intelegence dan tandatangan digital. Terkait dengan peningkatan teknologi tersebut Perbankan perlu mempersiapkan kompetensi yang dibutuhkan oleh Bankir agar dapat menutup gap tersebut.

\section{Kondisi Kompetensi MSDM Bankir di Indonesia}

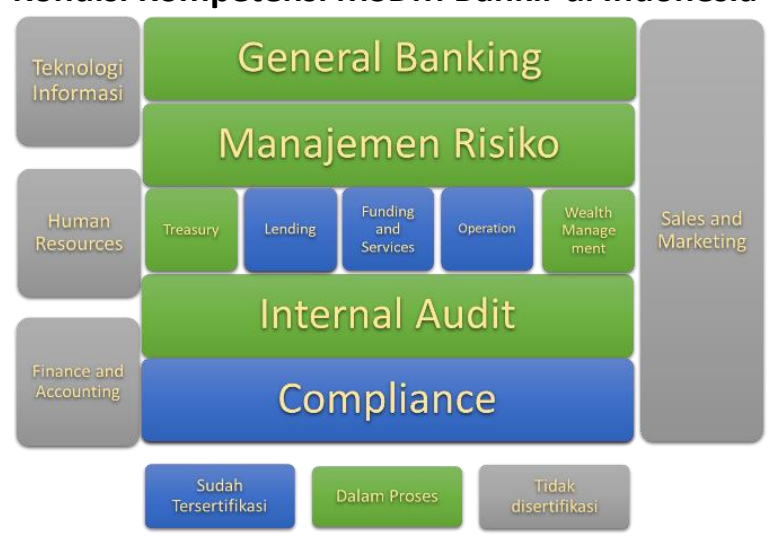

Gambar 9. Sertifikasi Kompetensi Bankir Indonesia 
Sumber: Data Lembaga Sertifikasi Profesi Perbankan (Diolah Kembali)

\section{Kompetensi SDM yang diperlukan}

Kompetensi perbankan menurut Lembaga Sertifikasi Profesi Perbankan (LSPP) secara umum terbagi menjadi : Manajemen Risiko, Treasury, Audit, Wealth Management, Compliance, Credit, Operation dan Funding \& Services. Sedangkan potensi kebutuhan sertifikasi perbankan terus meningkat dengan perkiran kebutuhan sertifikasi pada tahun 2019 sebanyak 1.064 .540 orang.

Tabel 6. Perkiraan Potensi Kebutuhan Sertifikasi Profesi Perbankan Tahun 2017 - 2019

\begin{tabular}{|lrrr|}
\hline Bidang Pekerjaan & \multicolumn{1}{c}{ 2017 } & \multicolumn{1}{l}{2018} & \multicolumn{1}{l}{2019} \\
\hline Compliance & 8.767 & 9.644 & 10.608 \\
\hline Internal Audit & 9.049 & 8.226 & 9.048 \\
\hline Operation & 132.504 & 145.755 & 160.330 \\
\hline Treasury & 5.514 & 6.066 & 6.672 \\
\hline $\begin{array}{l}\text { Risk Management } \\
\text { Specialist }\end{array}$ & 15.272 & 16.799 & 18.478 \\
\hline Funding and Services & 337.063 & 371.546 & 408.700 \\
\hline Credit & 81.949 & 90.144 & 99.158 \\
\hline Wealth Management & 55.928 & 61.520 & 67.672 \\
\hline Lainnya & 60.312 & 66.344 & 72.978 \\
\hline General Banking & 147.424 & 162.166 & 178.382 \\
\hline Risk Management & & & \\
Umum & 25.296 & 27.826 & 30.608 \\
\hline Total & 879.784 & 967.764 & 1.064 .540 \\
\hline Sumber: Data & & & \\
\hline
\end{tabular}

Sumber: Data Lembaga Sertifikasi Profesi Perbankan (Diolah Kembali)

\section{SIMPULAN}

Pada Era Fintech 4.0 perkembangan teknologi cukup berpengaruh pada sektor jasa keuangan dan memunculkan banyak pemain baru terutama perusahaan financial teknologi yang berkembang sangat pesat. Perkembangan ini berbanding teralik dengan perbankan yang memiliki beberapa kesamaan produk. Perbankan walaupun memiliki persamaan produk dengan perusahaan fintech akan tetapi memiliki karakter yang berbeda dimana perbankan memiliki prinsip kehati-hatian yang lebih tinggi.

Beberapa sektor dengan cukup bersinggungan dengan perbankan adalah bidang pembayaran dan pinjaman. Tingginya perkembangan produk fintech didukung dengan penggunaan inovasi teknologi ditambah berubahan pasar Indonesia yang cukup antusias dengan perkembangan teknologi digital. Inovasi produk dan penggunaan teknologi oleh E-KYC, Payment Gateway, Big Data, Cloud Infrastucture, Artificial Intelegence dan tandatangan digital oleh perusahaan fintech membuat fintech berkembang sangat pesat di masyarakat oleh karena itulah diperlukan peningkatan kompetensi bagi pegawai perbankan agar bisa bersaing dengan peningkatan kemampuan berinovasi dan kompeteni pegawai untuk dapat memanfaatkan teknologi terutama E-KYC, Payment Gateway, Big Data, Cloud Infrastucture, Artificial Intelegence dan tandatangan digital agar dapat berinovasi melauli produk digital.

Kondisi kompetensi kemampuan dasar perbankan di Indonesia sudah cukup baik akan tetapi untuk dapat bersaing di era fintech 4.0 kemampuan Teknologi yang sedang berkembang seperti blockchain, Al, dan RPA bagi pegawai Bank masih sangat baru bagi departemen TI bank-bank Indonesia. Seperti dalam survey bank digital 2018 PwC Lebih dari 40\% responden menilai keterampilan organisasi TI mereka saat ini dalam RPA dan Al buruk, dengan sekitar 56\% menunjukkan bahwa keterampilan TI dalam blockchain buruk. Hal ini merupakan masalah yang perlu ditangani di tahun-tahun mendatang, sehingga investasi yang tepat dapat dilakukan oleh bank-bank Indonesia dalam teknologi ini untuk mendapatkan keunggulan kompetitif di pasar.

Berdasarkan hal tersebut salah satu kompetensi yang sangat diperlukan oleh pegawai bank dalam menghadapai fintech 4.0 adalah E-KYC, Payment Gateway, Big Data, Cloud Infrastucture, Artificial Intelegence dan tandatangan digital selain itu juga diperlukannya kemampuan berinovasi, kemauan untuk belajar dan berubah, dan mampu memberikan dorongan kreatif di tempat mereka bekerja. mengeksplorasi proses yang berkaitan dengan TI mulai dari proses kerja yang dilakukan oleh organisasi, membantu mengatasi masalah yang ada hubungannya dengan $\mathrm{TI}$ dan juga pengembangan sistem $\mathrm{TI}$ sesuai dengan kebutuhan organisasi dan tuntutan yang ada. 


\section{DAFTAR PUSTAKA}

[1] Arthur W. Sherman, George W. Bohlander, Scott Snell, "Managing Human Resources". California: South-Western College Pub: 2001. Hal 4

[2] Baporikar, Neeta, Sony, Michael, Quality Management Principles and Policies in Higher Education IGI Global 2019. Hal. 86

[3] Davenport, "Human Capital: What It Is and Why People Invest It". San Francisco : JosseyBass:1999. Hal. 22.

[4] David D. Dubois, William J. Rothwell Competency-based human resource management English edition: 2004. Hal. 16

[5] Fitz-enz, Jac. The ROI of Human Capital: Measuring the Economic Value of Employee Performance. New York : AMACOM:2000. Hal. 6

[6] Hasibuan, Malayu S.P. Dasar-dasar Perbankan, PT Bumi Aksara: Jakarta.2009. Hal 12

[7] Hunter, G. Shawn. Out Think: How Innovative Leaders Drive Exceptional Outcomes, John Wiley and son. 2013. Hal. 4

[8] Ardela, Fransiska.Teknologi Finansial: Tengok Dulu Perkembangan Fintech Di Indonesia!, https://www.finansialku.com/perkembangan-

fintech-di-indonesia/ diakses 23 Desember 2019 pukul 14.15 WIB.

[9] Digital Banking in Indonesia 2018: Digital strategy as a corporate strategy. https://www.pwc.com/id/en/pwc-

publications/industries-publications/financial-

services-publications/digital-banking-survey2018.html diakses 2 Juni 2020 pukul 09.00 WIB.

[10] Gumiwang, Ringkang. Di Balik Jumlah Pegawai Bank yang Makin Susut https://tirto.id/di-balik-jumlah-pegawai-bankyang-makin-susut-dkrg diakses pada 10 Februari 2020 pukul 13.10 WIB

[11]Menyiapkan Kompetensi Bankir di Era Disrupsi Teknologi Finansial Lembaga Sertifikasi Profesi Perbankan Disampaikan dalam Seminar Nasional Vokasi Perbankan 2018 Yogyakarta, 18
Oktober 2018 https://lspp.or.id/ diakses pada 10 Februari 2020 pukul 14.30 WIB

[12] Setiawan, Sakina Rakhma Diah. Fintech 2.0 dan 3.0, Apa Bedanya?, Kompas Cyber Media, https://ekonomi.kompas.com/read/2017/09/25 /183423826/fintech-20-dan-30-apa-bedanya (diakses pada 28 Maret 2020, Pukul 15.30 WIB. [13] Survei Perbankan Triwulan I 2020 Pertumbuhan Triwulanan Kredit Baru Melambat. Departemen Komunikasi Bank Indonesia https://www.bi.go.id/id/ruang-media/infoterbaru/Pages/Survei-Perbankan-Triwulan-I2020-Pertumbuhan-Triwulanan-Kredit-BaruMelambat.aspx diakses pada 2 Juni 2020 pukul 12.30 WIB

[14] Statistik Perbankan Indonesia Desember 2019, Data Departemen Perizinan dan Informasi Perbankan Otoritas Jasa Keuangan, https://www.ojk.go.id/id/kanal/perbankan/data -dan-statistik/statistik-perbankan-

indonesia/default.aspx diakses pada 12 Maret 2020 pukul 10.20 WIB

[15] Statistik Fintech Lending Periode Desember 2019, Data Direktorat Pengaturan, Perizinan dan Pengawasan Fintech https://www.ojk.go.id/id/kanal/iknb/data-danstatistik/fintech/default.aspx diakses 2 Maret 2020 pukul 13.25 WIB

[16] Triyono. Presentasi Perkembangan Fintech, Grup Inovasi Keuangan Digital Otoritas Jasa Keuangan, 2019.

[17] Ulrich, Dave. Human Resource Competency Conference 2016, Michigan: Michigan Ross Excecutive Education, 2015.

[18] Barley, Tasa N. Direktur Asosiasi Fintech Indonesia (AFTECH), 5 Desember 2019 pukul 15.25 WIB

[19] Massie, Hugo. Asosiasi Fintech Pendanaan Bersama Indonesia (AFPI), 17 Desember 2019 Pukul10.17 WIB

[20] Triyono. Kepala Grup Inovasi Keuangan Digital Otoritas Jasa Keuangan, Senin, 25 November 2019 pukul 15.18 WIB 
